\title{
ПРОТИВОПОЖАРНЫЙ ПОТЕНЦИАЛ ЛЕСОВ ВОДООХРАННОЙ ЗОНЫ ОЗЕРА БАЙКАЛ (НА ПРИМЕРЕ ТЕРРИТОРИИ БАЙКАЛО-ЛЕНСКОГО ЗАПОВЕДНИКА)
}

\author{
(C) 2020 г. А. А. Медведков ${ }^{a, b}, *$, М. В. Котова ${ }^{a, ~ * *}$ \\ ${ }^{a}$ Московский государственный университет имени М.В. Ломоносова, Москва, Россия \\ ${ }^{b}$ Московский государственный областной университет, Москва, Россия \\ *e-mail: a-medvedkov@bk.ru \\ **e-mail: mariakot121212@gmail.com \\ Поступила в редакцию 13.09.2019 г. \\ После доработки 15.05.2020 г. \\ Принята к публикации 06.06.2020 г.
}

\begin{abstract}
Предложена методика оценки противопожарного потенциала разных типов леса, базирующаяся на обработке данных тепловой инфракрасной съемки со спутника Landsat TM и полученных на этой основе температур поверхности для лесных ландшафтов с разными биопродукционными характеристиками. Методика применена к условно-коренным лесам Байкало-Ленского государственного природного заповедника. Возможность использования температур поверхности для оценки противопожарной роли разных типов леса опирается на уравнение теплового баланса земной поверхности, учитывающее теплоту испарения (т.е. поток скрытого тепла) и турбулентный поток явного тепла от подстилающей поверхности. На основе анализа тепловых инфракрасных снимков получены термические значения, отражающие меру выброса ландшафтом потока явного тепла: чем он больше, тем меньше поток скрытого тепла в форме транспирации и физического испарения с растительного полога и, соответственно, выше значения приповерхностных температур, различающиеся по типам леса. Типы леса с наиболее высокой противопожарной ролью отличаются более высоким потенциалом влагообмена и наименьшими значениями приповерхностных температур. Их анализ вместе с показателями NDVI и NDMI и сведениями о зарегистрированных очагах пожаров за экстремально жаркие летние периоды с 2011 по 2017 гг. позволил выявить наиболее уязвимые к пожарам типы леса Байкало-Ленского заповедника. Наиболее пожароопасные лесные ландшафты в геоморфологическом отношении приурочены к долинам межгорных понижений, низинам, днищам котловин, предгорным возвышенностям и пологим склонам - в разной степени переувлажненным территориям с островами льдистых пород и низкими значениями фитомассы. Эти природные комплексы наиболее пожароопасны в периоды продолжительных засух, что обусловлено их пониженным транспирационным потенциалом в сравнении с лесами на талых породах.
\end{abstract}

Ключевые слова: природные факторы пожароопасности, горимость леса, сибирская тайга, транспирационный потенциал, тепловой инфракрасный диапазон, лес на мерзлоте, Байкальская природная территория

DOI: $10.31857 / \mathrm{S} 2587556620050118$

\section{ВВЕДЕНИЕ}

Леса, окружающие объект Всемирного природного наследия - оз. Байкал, имеют важнейшее значение для сохранения его экосистемы благодаря их водо- и климаторегулирующим, почвозащитным и другим функциям. Такая роль лесных ландшафтов предполагает глубокий контроль их состояния, в том числе - охрану от лесных пожаров. При обычных погодных условиях в байкальских лесах за год возникает около 700900 пожаров, но в годы погодных аномалий частота горения лесов может возрастать в 3-4 раза [15]. Последствия пожаров особенно ощутимы в горно-таежных ландшафтах с высоким денудационным потенциалом и значительной водоохран- ной ролью для Байкала. Их разрушительное воздействие усиливается природно-климатическими особенностями горной территории, где восстановление леса и его средозащитных функций замедлено.

В настоящее время ландшафты Байкальского региона испытывают воздействие потепления климата. Рост среднегодовой температуры приземного воздуха в этом регионе существенно превышает средние значения по миру [27, 35]. Так, темп роста сезонной (май-октябрь) температуры приземного воздуха за период 1976-2015 гг. составлял $+0.37^{\circ} \mathrm{C} / 10$ лет [31]. В связи с усилением частоты засух в зоне водосбора к 2014 г. доля поверхностной составляющей стока снизилась бо- 
лее чем на 50\%. Причем данная ситуация сохранялась и в течение 2015-2016 гг. Наряду с этим проявляется активизация таяния льдистых пород [30]. Данные обстоятельства и рост продолжительности пожароопасного периода (в среднем до 170 дней) за последние 40 лет [19] способствуют увеличению опасности лесных пожаров в водоохранной зоне Байкала. Эта тенденция характерна не только для Байкальской природной территории, но и для других регионов Сибири. В результате многолетнего (1996-2016) спутникового мониторинга выявлено, что за этот период горимость сибирских лесов выросла [29]. Она влияет не только на темпы обезлесения в Байкальском регионе, но также и на другие, менее очевидные процессы, приводящие к ухудшению экологической обстановки и снижению качества экосистемных услуг местных природных геосистем. Среди неблагоприятных последствий - увеличение доли поверхностного стока и снижение питания его подземной составляющей, уменьшение потока скрытого тепла в форме транспирации и снижение потенциала влагообмена, разрушение почвенного покрова и ухудшение системы очистки фильтрующейся дождевой воды, размыв поверхностных отложений, подавление функции по ассимиляции загрязняющих веществ, выносу тяжелых металлов и искусственных радионуклидов, а также трансформация других природно-экологических процессов. Среди особенно ярких откликов обнаружение корреляционной связи между горимостью лесов и появлением сакситоксина - органического вещества, поражающего байкальские губки, очищающие озерные воды Байкала. Также имеется предположение о влиянии пожаров на поток аммония и других биогенов [36], способствующих распространению спирогиры - еще одной угрозы для эндемичных байкальских губок и озерной экосистемы в целом.

В регионе проведены многочисленные лесопирологические исследования. В них рассматривается, в первую очередь, такой фактор пожароопасности, как наличие лесных горючих материалов (ЛГМ) - потенциально пожароопасных растительных остатков разной степени разложения [18]. Роль данного фактора прослеживается в современных работах по лесной экологии и лесоведению $[7,8,34]$. Отметим, что на сегодняшний день в лесной пирологии отсутствует общепринятая классификация ЛГМ, что затрудняет обработку фиксируемых в ходе лесоустройства данных [14]. Географизация данного подхода заключается в учете факторов лесопирологического "созревания" по отдельным ландшафтным комплексам, включая высотно-поясную дифференциацию, что находит отражение в современных работах по данной проблеме [15]. В Канаде и США используются национальные классификации ЛГМ и подходы к их картографированию [37, 40], имеющие свою специфику. Это затрудняет их использование в российских условиях.

На фактическую горимость лесов региона оказывают влияние не только характеристики ЛГМ территории, но также ее микро- и мезоклиматические особенности, обусловленные в значительной степени ландшафтно-геофизическими особенностями типа леса и совокупностью его лесорастительных условий. Данное обстоятельство подчеркивает необходимость исследования других факторов, влияющих на лесопирологическую обстановку, помимо собственно запасов горючих растительных материалов. Для наиболее полной и более достоверной оценки факторов, влияющих на пожароопасную ситуацию, предлагается рассматривать транспирационный потенциал типов леса. Данное предложение обосновано тем, что весь обмен водяного пара в лесу связан с испарением, перехватом осадков растительностью и транспирацией в форме переноса влаги в приземную часть атмосферы [32]. В этом проявляется роль лесного массива в формировании своего теплового режима при разных типах погод [10]. Ю.В. Карпечко и Н.Л. Бондарик [17] выявили “цену” класса бонитета в величине транспирации от общего испарения. В условиях южной полосы криолитозоны наличие льдистых пород - важнейший фактор, влияющий на бонитетные характеристики древостоя как показателя местообитания. Таким образом, лесорастительные условия влияют на температурный режим лесного массива [9]. Общеизвестно, что помимо прироста древесины транспирация зависит и от состава древостоя. Выявлено, что тепловое излучение выступает в качестве индикатора характеристик растительного покрова [39, 41]. Поэтому оценка транспирационного потенциала разных типов леса и выполненное на этой основе их ранжирование по противопожарной функции может быть произведено по результатам анализа тепловых инфракрасных снимков в форме термических характеристик дневной поверхности. Идея использования приповерхностных температур в качестве критерия дифференциации лесов бореальной криолитозоны по их противопожарному потенциалу принадлежит А.А. Медведкову [23], который опирался на вывод С.П. Горшкова [13] о том, что температура поверхности в пределах периода активной вегетации служит одним из важнейших показателей средообразующей гомеостатической функции лесов. Тогда как в подавляющем большинстве эколого-экономических работ, например, С.Н. Бобылева и А.В. Стеценко [4], климаторегулирующая роль леса рассматривается преимущественно с позиции депонирования углерода, что является недостаточным для объективной оценки экосистемных услуг лесных территорий. В связи с этим ряд эколого-экономических индексов, пользующихся популярностью [3], требуют серьезной доработки [12]. 


\section{МЕТОДЫ И ОБЪЕКТ ИССЛЕДОВАНИЯ}

Современные технологии дистанционного зондирования Земли позволяют оперативно отслеживать геофизические параметры функционирования ландшафтов на различных пространственных уровнях. Применительно к рассматриваемой в статье проблеме это возможно за счет привлечения данных тепловой инфракрасной съемки и полученных на этой основе карт температур поверхности. Таким образом, тепловое изображение на основе интенсивности теплового излучения позволяет выявлять самые разные ландшафты [2].

В рамках исследования природных факторов пожароопасности особый интерес представляют условно-коренные ландшафты со строгим режимом охраны, где антропогенное влияние практически полностью исключено. В связи с чем, применительно к задачам данного исследования и учитывая степень ландшафтного разнообразия (в том числе бореальных лесов), нами в качестве репрезентативной была выбрана территория Байкало-Ленского государственного заповедника. Он располагается в области распространения прерывистой и островной вечной мерзлоты, что наряду с горным рельефом существенно повышает мозаичность природно-ландшафтных условий исследуемой территории [1]. В заповеднике представлены все основные типы природных комплексов Прибайкалья: нивальные и гольцовые, горно-таежные, лесостепные, степные и прибрежные. Самую большую площадь занимают леса (более $85 \%$ ), основная часть которых представлена хвойными породами: лиственницами сибирской и Чекановского (переходным видом к лиственнице Гмелина), сосной обыкновенной, кедром сибирским, елью сибирской и и пихтой сибирской. Из мелколиственных пород встречаются осина, ивы и береза. В переувлажненных низинах и долинах широко распространены ерниковые ландшафты, а по горным склонам - заросли кедрового стланика. На них приходится около $20 \%$ территории заповедника. При ослабленной средообразующей роли лесов в криолитозоне такие ландшафты выполняют существенные защитные функции [28].

Известно, что ландшафты бореальной криолитозоны наиболее уязвимы к пожарам в летние периоды с продолжительными засухами. В данной работе нами рассматривались изображения спутниковой системы Landsat-8, полученные не только за периоды с активной вегетацией, но и с наблюдающимися стабильно высокими температурами воздуха и засушливой погодой в 2013, 2014 и 2015 гг. Так, для Байкало-Ленского заповедника отобраны летние безоблачные сцены Landsat-8. Поиск и заказ снимков осуществлялся через вебсервис EarthExplorer. Далее проводилась обработка дистанционных данных теплового диапазона, вычислялись по стандартной формуле приповерхностные температуры и создавались картографические изображения теплового поля.

Исходя из анализа тепловых инфракрасных снимков, обобщения результатов полевых исследований в аналогичных условиях [25] и опубликованных материалов [2], было установлено, что распределение интенсивности теплового излучения зависит от мощности растительного покрова (т.е. запасов фитомассы). Данный факт получил подтверждение по результатам расчета нормализованного относительного индекса растительности (NDVI) и стандартизованного индекса различий увлажненности (NDMI) и их последующего сопоставления с картами температур поверхности. Особенность индекса NDMI - относительно высокая чувствительность к запасам влаги в растительной массе. Данное его свойство позволяет уточнять результаты расчета NDVI в части выявления старых гарей и других природных комплексов с пониженными биопродукционными характеристиками. Данные показатели позволили также оценить соотношение вегетирующей и отмершей растительности [14].

В рамках данного исследования были использованы другие материалы и методические приемы: цифровая модель рельефа (ЦМР), созданная на основе данных радарной топографической съемки SRTM; данные об административных границах заповедника, предоставленные БД по федеральным ООПТ РФ (http://geoportal.aari.ru/). Для уточнения полученных результатов были использованы различные картографические материалы и открытые данные ГИС-порталов (карта пожаров СКАНЭКС - https://fires.ru/, цифровые ландшафтные карты и др.). Для анализа и обработки данных использовалось программное обеспечение ArcGIS и QGIS.

\section{РЕЗУЛЬТАТЫ И ИХ ОБСУЖДЕНИЕ}

Анализ приповерхностных температур, показателей NDVI и NDMI и информации об очагах пожаров за экстремально жаркие летние периоды 2011-2017 гг. на территории Байкало-Ленского заповедника позволил выделить наиболее уязвимые к пожарам лесные ландшафты (рис. 1, 2). Выявлена взаимосвязь между значениями полученных показателей и фактической горимостью лесов. Отметим, что высокая мозаичность природно-ландшафтных условий местами усиливает дисперсию термических характеристик, что в некоторой степени осложняет проведение анализа полученных результатов. Тем не менее можно говорить о хорошо выраженной взаимосвязи между рассматриваемыми показателями и очагами возгорания. Ранжирование разных типов леса произвоилось по результатам анализа температурных карт, по- 
лученных путем обработки данных со спутников c Landsat-TM. В этом отношении методически мы базируемся на положении М.И. Будыко [6], что уравнение теплового баланса суши для среднего годичного периода имеет вид $R=L E+P$, где $L E-$ теплота испарения (поток скрытого тепла) и $P$ турбулентный поток явного тепла от подстилающей поверхности. Так как параметр $L E$ напрямую связан с состоянием и типом растительности, представляется возможным установить корреляционную связь между характеристиками растительного покрова и потоком явного тепла, выраженного в форме приповерхностной температуры. Для того чтобы оценить поведение турбулентных потоков в ходе водоэнергетического обмена, необходимо выявить их пространственное распределение над различными в биогеофизическом отношении типами подстилающей поверхности [33], что возможно выполнить с использованием ДДЗ. Подобные вопросы изучаются и с помощью самолетных исследований турбулентных потоков тепла и влаги от подстилающей поверхности умеренных широт [38, 42]. Тип леса влияет на значение приповерхностных температур и от него зависит транспирационный потенциал массива. При этом, чем выше поток явного тепла от поверхности, тем ниже поток скрытого тепла в форме транспирации. Транспирация подразумевает испарение с поверхности растительного покрова, поэтому можно говорить о том, что при увеличении значений потока явного тепла снижается роль ландшафта во влагообмене. Ландшафт с минимальным выбросом явного тепла имеет самый высокий потенциал влагообмена и более низкие значения поверхностной температуры [13, 22].

Все это позволило сопоставить разные типы лесных ландшафтов по их участию в водоэнергетическом обмене. На основе этого была составлена карта, отображающая структуру таежных ландшафтов Байкало-Ленского заповедника и их противопожарную устойчивость (см. рис. 1 и табл. 1). В ходе сравнительной оценки изначально выделялись и нелесные ландшафты (гольцовые и горно-тундровые), не рассматриваемые в рамках данной статьи. Отметим, что они, а также гари характеризуются в летний период очень сухими условиями и высокими значениями приповерхностных температур $\left(35-40^{\circ} \mathrm{C}\right.$ и более), что объясняется их небольшими в сравнении с лесами запасами живой фитомассы и незначительным транспирационным потенциалом. Соседство с такими комплексами приводит к тому, что гипсометрически ниже расположенные леса часто загораются от огня, очаг которого располагается выше (в нелесной зоне). Подобные явления происходили при катастрофических пожарах лета 2015 г., когда горно-тундровые ландшафты оказались источниками возгораний и фактором распространения огня на соседние ландшафты.

Выявленная взаимосвязь между потоками явного тепла и горимостью лесных ландшафтов позволила дифференцировать природные комплексы по их противопожарному потенциалу на пять основных категорий (см. рис. 2). Нами проведен анализ ландшафтно-географических факторов, обусловливающих противопожарный потенциал каждой из рассматриваемых категорий.

Для лесных ландшафтов с очень низкой противопожарной устойчивостью характерны относительно высокие значения $\left(30^{\circ} \mathrm{C}\right.$ и выше) приповерхностных температур и пониженные значения NDVI. Они занимают более половины территории заповедника $(68.8 \%)$. В геоморфологическом отношении такие природные комплексы приурочены к долинам и межгорным понижениям, днищам котловин, низинам и склонам с незначительной крутизной, перекрытым дисперсными отложениями. Здесь формируются условия с застойным режимом увлажнения, что способствует сохранению льдистых пород и их широкому распространению. Данные факторы ухудшают лесорастительные условия, что способствует увеличению потока явного тепла в связи с пониженной транспирирующей ролью растительного покрова в рассматриваемой обстановке. Здесь получили развитие ерниковые заросли и угнетенные формы лиственнично-еловой, кедрово-лиственничной, елово-кедровой и пихтовокедровой тайги.

Для природных комплексов с низкой устойчивостью также типичны относительно высокие значения приповерхностных температур $\left(25^{\circ} \mathrm{C}\right.$ и выше) и пониженные значения NDVI. На эти геосистемы приходится $7.2 \%$ площади заповедника, их древесная растительность представлена пихтово-кедровой и лиственничной тайгой с характерными признаками угнетенности. Данные геосистемы по своей биогеофизической роли и формирующим их лесорастительным условиям схожи с предыдущим типом. Отличие состоит в том, указанные лесные комплексы существуют в условиях лучшей дренированности и характеризуются большими запасами живой фитомассы. Более высокая степень дренированности обусловлена широким распространением обломочных пород и большей крутизной склоновых поверхностей.

Лесные ландшафты со средней противопожарной устойчивостью обладают промежуточными (в сравнении с другими) значениями приповерхностных температур $\left(\sim 20-25^{\circ} \mathrm{C}\right)$ и повышенными или средними значениями NDVI. Занимаемая ими площадь составляет только 2.8\%. Данные комплексы состоят из кедрово-пихтовой и кедрово-лиственничной тайги оптимального развития 


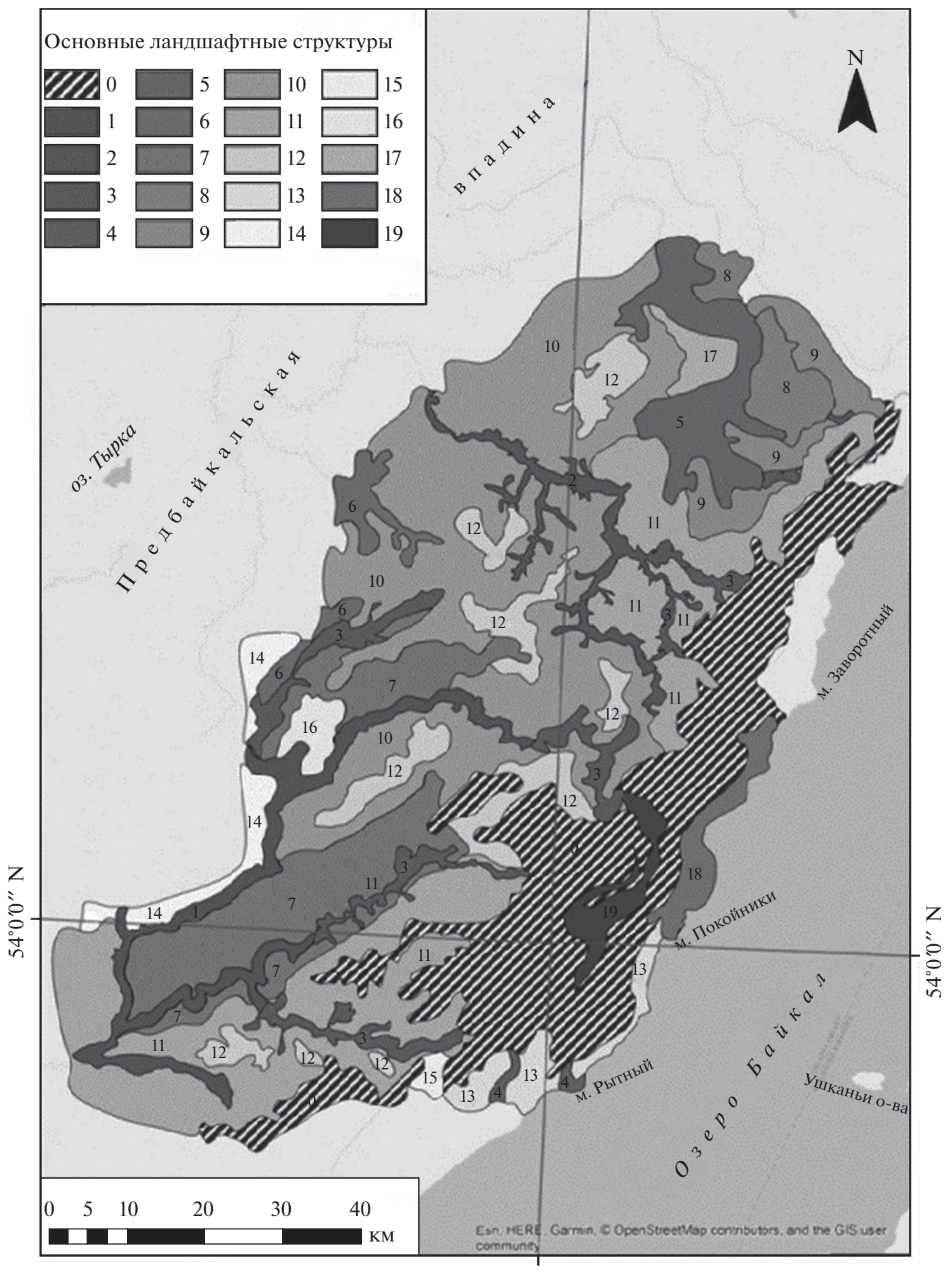

Рис. 1. Структура таежных ландшафтов Байкало-Ленского заповедника и их противопожарная устойчивость . Составлено авторами. Пояснения к легенде см. табл. 1.

с фрагментами лугово-степной растительности. Они приурочены преимущественно к выходам плотных карбонатных пород, перекрытых чехлом из обломочных отложений, а в рельефе представ- лены склоны средней крутизны и предгорные возвышенности.

Высоко устойчивые лесные ландшафты имеют сравнительно низкие значения приповерхност- 


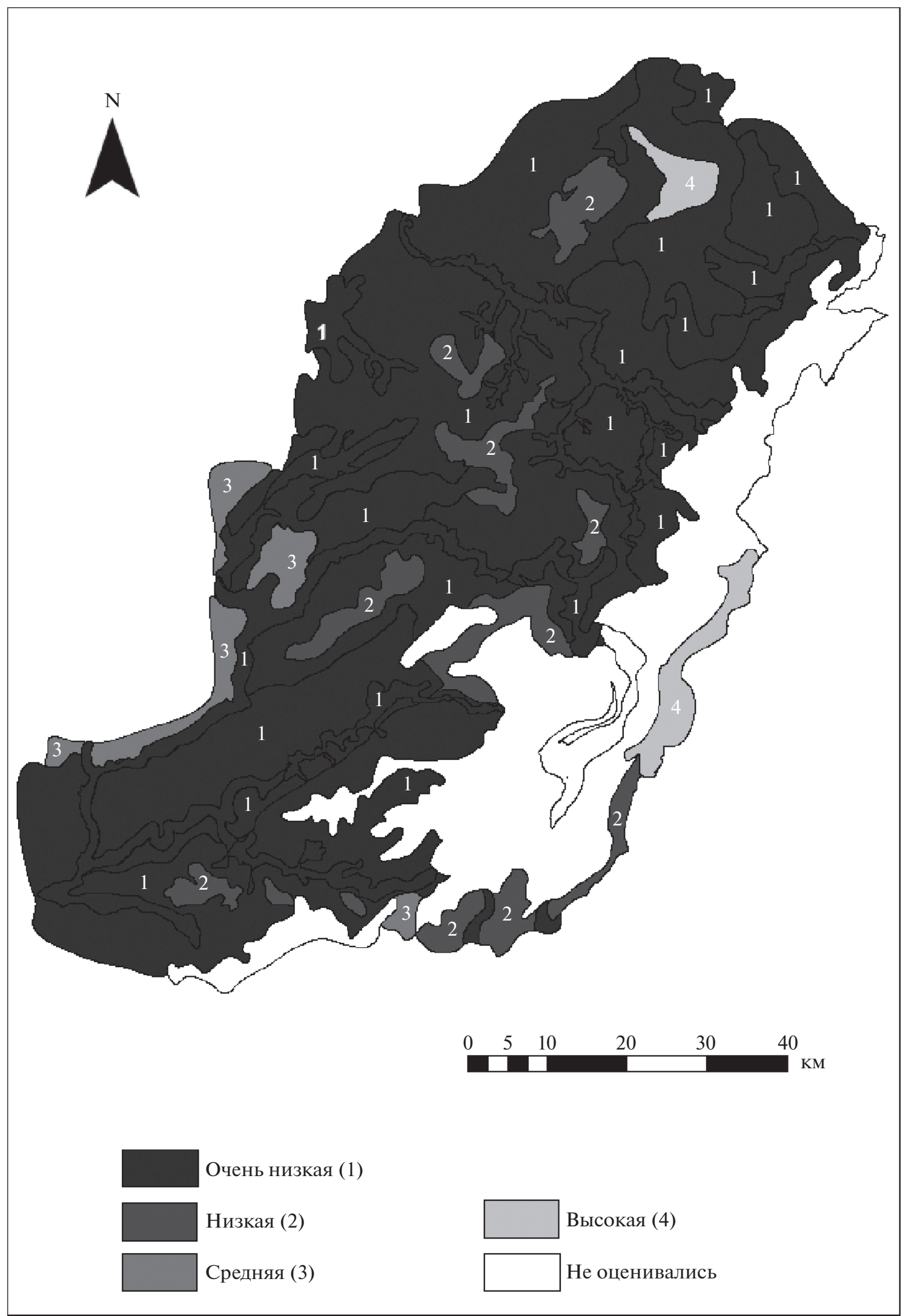

Рис. 2. Ранжирование таежных ландшафтов Байкало-Ленского заповедника по их противопожарной устойчивости. Составлено авторами. 
Таблица 1. Структура таежных ландшафтов Байкало-Ленского заповедника и их противопожарная устойчивость

\begin{tabular}{|c|c|c|c|}
\hline № & Основные ландшафтные структуры & $\begin{array}{l}\text { Доля } \\
\text { занимаемой } \\
\text { территории, } \\
\%\end{array}$ & $\begin{array}{l}\text { Противопожарная } \\
\text { устойчивость } \\
\text { лесных ландшафтов }\end{array}$ \\
\hline 1 & $\begin{array}{l}\text { Долины межгорных понижений, выработанные в кристаллических } \\
\text { породах и перекрытые дисперсными отложениями под ерниковыми } \\
\text { зарослями на аллювиальных торфяно-болотных мерзлотных почвах }\end{array}$ & 3.64 & Очень низкая \\
\hline 2 & $\begin{array}{l}\text { Долины межгорных понижений, выработанные в кристаллических } \\
\text { породах и перекрытые дисперсными отложениями под лиственнично- } \\
\text { еловой тайгой ограниченного развития на аллювиальных торфяно- } \\
\text { болотных мерзлотных почвах }\end{array}$ & 2.06 & Очень низкая \\
\hline 3 & $\begin{array}{l}\text { Долины межгорных понижений, выработанные в кристаллических } \\
\text { породах и перекрытые дисперсными отложениями под елово-кед- } \\
\text { рово-пихтовой тайгой ограниченного развития на аллювиальных дер- } \\
\text { ново-луговых и торфяно-болотных мерзлотных почвах }\end{array}$ & 3.75 & Очень низкая \\
\hline 4 & $\begin{array}{l}\text { Долины межгорных понижений, выработанные в кристаллических } \\
\text { породах и перекрытые дисперсными отложениями под заболоченной } \\
\text { лиственнично-кедрово-еловой тайгой ограниченного развития на } \\
\text { аллювиальных торфяно-болотных мерзлотных почвах }\end{array}$ & 0.25 & Очень низкая \\
\hline 5 & $\begin{array}{l}\text { Низины, выработанные в кристаллических породах и перекрытые } \\
\text { дисперсными отложениями под заболоченной лиственнично-елово- } \\
\text { кедровой тайгой ограниченного развития на дерново-глеевых мерз- } \\
\text { лотных почвах }\end{array}$ & 4.00 & Очень низкая \\
\hline 6 & $\begin{array}{l}\text { Днища котловин, выработанные в кристаллических породах и пере- } \\
\text { крытые дисперсными отложениями под кедрово-лиственничной тай- } \\
\text { гой ограниченного развития с выраженным кустарничковым } \\
\text { подлеском на дерново-мерзлотных и мерзлотно-таежных карбонат- } \\
\text { ных почвах }\end{array}$ & 1.46 & Очень низкая \\
\hline 7 & $\begin{array}{l}\text { Днища котловин, выработанные в кристаллических породах и пере- } \\
\text { крытые дисперсными отложениями под кедрово-лиственничной тай- } \\
\text { гой ограниченного развития с ерниковым подлеском на дерново- } \\
\text { мерзлотных почвах }\end{array}$ & 8.82 & Очень низкая \\
\hline 8 & $\begin{array}{l}\text { Предгорные возвышенности, выработанные в кристаллических слан- } \\
\text { цах и известняках, перекрытые дисперсными отложениями под пих- } \\
\text { тово-кедровой тайгой ограниченного развития с выраженным } \\
\text { кустарничковым подлеском на дерново-мерзлотных и мерзлотно- } \\
\text { таежных карбонатных почвах }\end{array}$ & 2.00 & Очень низкая \\
\hline 9 & $\begin{array}{l}\text { Склоны пологие, выработанные в кристаллических сланцах и пере- } \\
\text { крытые дисперсными отложениями под заболоченной лиственнично- } \\
\text { елово-кедровой тайгой ограниченного развития с кустарничковым } \\
\text { подлеском (с преобладанием голубики) на буротаежных мерзлотных } \\
\text { почвах }\end{array}$ & 2.66 & Очень низкая \\
\hline 10 & $\begin{array}{l}\text { Предгорные возвышенности, выработанные в кристаллических слан- } \\
\text { цах и известняках, перекрытые дисперсными отложениями под пих- } \\
\text { тово-кедровой тайгой ограниченного развития с выраженным } \\
\text { кустарничковым подлеском на дерново-мерзлотных и мерзлотно- } \\
\text { таежных карбонатных почвах }\end{array}$ & 20.8 & Очень низкая \\
\hline 11 & $\begin{array}{l}\text { Склоны средней крутизны, выработанные в кристаллических сланцах } \\
\text { и перекрытые обломочными отложениями под пихтово-кедровой тай- } \\
\text { гой ограниченного развития, местами с баданом на горных дерново- } \\
\text { мерзлотных и горных буротаежных мерзлотных почвах }\end{array}$ & 19.37 & Очень низкая \\
\hline
\end{tabular}


Таблица 1. Окончание

\begin{tabular}{|c|c|c|c|}
\hline № & Основные ландшафтные структуры & $\begin{array}{l}\text { Доля } \\
\text { занимаемой } \\
\text { территории, } \\
\%\end{array}$ & $\begin{array}{l}\text { Противопожарная } \\
\text { устойчивость } \\
\text { лесных ландшафтов }\end{array}$ \\
\hline 12 & $\begin{array}{l}\text { Плоские поверхности, выработанные в кристаллических сланцах и } \\
\text { перекрытые обломочными отложениями под пихтово-кедровой тай- } \\
\text { гой ограниченного развития с выраженным кустарничковым под- } \\
\text { леском на горных дерново-мерзлотных почвах }\end{array}$ & 5.56 & Низкая \\
\hline 13 & $\begin{array}{l}\text { Склоны средней крутизны и крутые, выработанные в кристалличе- } \\
\text { ских сланцах и перекрытые обломочными отложениями под листвен- } \\
\text { ничной тайгой ограниченного развития с кустарниковым подлеском } \\
\text { (с преобладанием рододендрона даурского) на горных буротаежных } \\
\text { почвах }\end{array}$ & 1.62 & Низкая \\
\hline 14 & $\begin{array}{l}\text { Склоны средней крутизны, выработанные в плотных карбонатных } \\
\text { породах и перекрытые обломочными отложениями под светлохвой- } \\
\text { ной тайгой ограниченного развития с примесью ели и кедра на мерз- } \\
\text { лотно-таежных карбонатных почвах и дерново-карбонатных } \\
\text { длительно промерзающих почвах }\end{array}$ & 1.79 & Средняя \\
\hline 15 & $\begin{array}{l}\text { Склоны средней крутизны, выработанные в плотных карбонатных и } \\
\text { других кристаллических породах, перекрытые обломочными отложе- } \\
\text { ниями под кедрово-пихтовой тайгой оптимального развития на дер- } \\
\text { ново-карбонатных почвах }\end{array}$ & 0.25 & Средняя \\
\hline 16 & $\begin{array}{l}\text { Предгорья с возвышенностями, выработанные в плотных карбонат- } \\
\text { ных породах и перекрытые обломочными отложениями под кедрово- } \\
\text { лиственничной тайгой оптимального развития с фрагментами степ- } \\
\text { ной растительности на дерново-подзолистых и дерновых остаточно- } \\
\text { карбонатных длительно промерзающих почвах }\end{array}$ & 0.76 & Средняя \\
\hline 17 & $\begin{array}{l}\text { Склоны средней крутизны, выработанные в плотных карбонатных и } \\
\text { других кристаллических породах, перекрытые обломочными отложе- } \\
\text { ниями под кедрово-пихтовой тайгой оптимального развития на дер- } \\
\text { ново-карбонатных почвах }\end{array}$ & 0.78 & Высокая \\
\hline 18 & $\begin{array}{l}\text { Днища котловин, выработанные в кристаллических породах и пере- } \\
\text { крытые обломочными отложениями под сосновой тайгой с кустарни- } \\
\text { ковым подлеском на буротаежных почвах }\end{array}$ & 1.39 & Высокая \\
\hline 19 & $\begin{array}{l}\text { Предгорья с наклонными равнинами, выработанные в кристалличе- } \\
\text { ских породах и перекрытые обломочными отложениями под участ- } \\
\text { ками травяных сосновых лесов и дерновинно-злаковыми степями на } \\
\text { дерново-луговых и каштановых почвах }\end{array}$ & 1.22 & $\begin{array}{l}\text { Лесные пожары } \\
\text { не типичны (ввиду } \\
\text { преобладания луго- } \\
\text { вой растительности) }\end{array}$ \\
\hline
\end{tabular}

ных температур ( $\left.15-20^{\circ} \mathrm{C}\right)$ и повышенные показатели индекса NDVI. На данные природные комплексы приходится 2.2\% площади заповедника, к ним отнесены леса оптимального развития, представленные кедрово-пихтовой и сосновой тайгой. Последняя - с хорошо развитым кустарниковым подлеском приурочена к дренируемым днищам котловин, которые сложены обломочными породами. Кедрово-пихтовая тайга с наибольшими для территории заповедника запасами фитомассы получила развитие на склонах средней крутизны, выработанных в плотных карбонатных и других кристаллических породах. Общеизвестно, что на- личие карбонатных пород сказывается на увеличении биологической продуктивности фитоценозов. Так, леса, произрастающие на карбонатных отложениях, обладают большими запасами фитомассы, что фиксируется по результатам оценки индекса NDVI. Такие комплексы активнее участвуют во влагообмене, что делает их климатически более значимыми.

По результатам анализа можно заключить, что в условиях продолжительных засушливых периодов наименее устойчивыми к пожарам оказываются ландшафты на льдистых породах. Это обусловлено пониженными значениями их транспи- 
рационного потенциала и ослабленной в связи с этим их водоэнергетической ролью. Так, при изучении пожаров за жаркие и сухие летние периоды 2011-2017 гг. было отмечено, что значительная часть очагов возгорания на территории заповедника приурочена к избыточно увлажненным долинным и днищевым комплексам. В таких гипсометрических понижениях формируется застойный тип водного режима, что способствуют сохранению льдистых пород. Многолетнемерзлые породы участвуют в создании особой структуры растительного покрова (угнетенность и разреженность древостоя, широкое распространение ерников, низкий биопродукционный потенциал). Это обусловливает повышенные термические характеристики данных ландшафтов на картах приповерхностных температур [5, 22]. В ходе экспериментальных исследований Э.П. Галенко [11] выявлено, что для разреженных лесов в малооблачные дни в среднем величины турбулентного теплообмена (P) высоки и сравнимы с затратами тепла на суммарное испарение (LE). В продолжительные периоды с сухой погодой такие ландшафты с большими размерами межкроновых просветов быстрее прогреваются и иссушаются, вследствие чего их обводненность сильно снижается. С этим и связана высокая горимость мерзлотно-таежных ландшафтов. Также следует отметить, что определенную роль в этом играют и торфянистые почвы, которые при обсыхании минерализуются. Известно, что снижение относительной влажности воздуха на $50 \%$ увеличивает пожароопасность из-за высыхания имеющихся горючих материалов [20]. Предложенная в данной работе методика представляется важной для создания эффективной системы лесного мониторинга и предотвращения широкомасштабных пожаров в годы с экстремально засушливыми погодными условиями.

\section{ЗАКЛЮЧЕНИЕ}

По результатам настоящего исследования можно заключить, что основными факторами, определяющими лесорастительные условия, запасы фитомассы и, как следствие, транспирационный потенциал лесов на Байкальской природной территории в пределах южной криолитозоны, являются: (1) морфометрические особенности территории, (2) состав поверхностных отложений, (3) степень дренированности почвогрунтов, (4) наличие льдистых пород и характер их распространения. Многолетнемерзлые породы ухудшают лесорастительные условия через сформированный данным фактором неблагоприятный гидроклиматический режим и обусловленный им замедленный биологический круговорот вещества. Таким образом, влияние льдистых пород проявляется в снижении биопродукционного и транспирационного потенциала лесов. Ареалы таких природных комплексов отчетливо фиксируются на картах приповерхностных температур [21].
При ранжировании бореальных лесов по противопожарному потенциалу используются средние значения приповерхностных температур относительно однородных по растительному покрову ландшафтных таксонов.

Выявлено, что более $75 \%$ территории БайкалоЛенского заповедника характеризуются наибольшей уязвимостью к лесным пожарам. Наиболее пожароопасные лесные ландшафты оказались приуроченными к долинам межгорных понижений, низинам, днищам котловин, предгорным возвышенностям и пологим склонам - в разной степени переувлажненным территориям с островами льдистых пород и низкими значениями фитомассы. Данные природные комплексы представлены ерниковыми зарослями и редкостойной тайгой, которые в летние периоды с продолжительной засухой не выполняют роль противопожарных барьеров и являются источниками повышенной пожароопасности. Указанное обстоятельство обусловливает необходимость учета биогеофизической специфики разных типов леса. Комплексная оценка потенциала горимости ландшафтов необходима для управления пожарной обстановкой на значительных площадях с самыми разными лесорастительными условиями. Это представляется важным для прогнозирования пожарной обстановки и проведения специальных защитных мероприятий как на территории Байкало-Ленского заповедника, с учетом его функционального зонирования, так и на остальной части водоохранной зоны озера Байкал. Полученные результаты позволяют более обоснованно подходить к прогнозу пожарной ситуации в регионе и оптимизировать выбор проводимых противопожарных мероприятий, адаптировав их к индивидуальным особенностям конкретного ландшафта.

\section{СПИСОК ЛИТЕРАТУРЫ}

1. Байкал. Атлас / Под ред. Г.И. Галазия. М.: Роскартография, 1993. $160 \mathrm{c.}$

2. Балдина Е.А., Грищенко М.Ю. Методика дешифрирования разновременных космических снимков в тепловом инфракрасном диапазоне // Вестн. Моск. ун-та. Сер. 5. География. 2014. № 3. С. 35-41.

3. Бобылев С.Н., Минаев В.С., Соловьев С.В., Третьяков B.B. Эколого-экономический индекс регионов Российской Федерации. М.: WWF, 2012. 150 c.

4. Бобылев С.Н., Стеценко А.В. Лесные проекты: климатические изменения и экосистемные услуги // Тр. Санкт-Петербургского науч.-исслед. ин-та лесного хоз-ва. 2016. № 3. С. 77-89.

5. Борисов Б.З., Фёдоров П.П., Чикидов И.И., Десяткин A.P. Выделение многолетнемерзлых пород в зоне их островного распространения по тепловым каналам спутниковых снимков Landsat-7 ETM+ // Успехи совр. естествознания. 2017. № 5. С. 78-82.

6. Будыко М.И. Глобальная экология. М.: Мысль, $1977.328 \mathrm{c}$.

7. Волокитина А.В. Совершенствование оценки природной пожарной опасности в заповедниках // География и природные ресурсы. 2017. № 1. С. 55-61. 
8. Волокитина А.В., Софронов А.М. Классификация и картографирование растительных горючих материалов. Новосибирск: СО РАН, 2002. 306 с.

9. Выхристюк М.М. Фитоклимат прибрежных лесов северного Байкала. Новосибирск: Наука, 1980. 216 с.

10. Галенко Э.П. Температурный режим воздуха старовозрастного ельника средней тайги // Изв. ВУЗов. Лесной журн. 2013. № 3. С. 45-56.

11. Галенко Э.П. Энергетические факторы продуктивности хвойных лесов северной тайги // Изв. АН СССР. Сер. геогр. 1976. № 4. С. 84-89.

12. Горшков С.П. Интегральные эколого-экономические индексы и проблема Киотского протокола // Пробл. регион. экологии. 2013. № 4. С. 256-261.

13. Горшков С.П. Организованность биосферы и устойчивое развитие // Жизнь Земли. 2015. Т. 37. С. 62-84.

14. Гусев В.Г., Лопухова Е.Л., Дубовый В.К. Классификация и общие свойства лесных горючих материалов // Изв. ВУЗов. Лесной журнал. 2012. № 1 (325). C. $134-145$.

15. Евдокименко М.Д. Факторы горимости Байкальских лесов // География и природные ресурсы. 2011. № 3. С. 51-57.

16. Золотокрылин А.Н. Климатическое опустынивание. М.: Наука, 2003. 246 с.

17. Карпечко Ю.В., Бондарик Н.Л. Гидрологическая роль лесохозяйственных и лесопромышленных работ в таежной зоне Европейского Севера России. Петрозаводск: КарНЦ РАН, 2010. 225 с.

18. Курбатский Н.П. Исследование количества и свойств лесных горючих материалов // Вопр. лесной пирологии. Красноярск: Ин-т леса и древесины СО АН СССР, 1970. С. 5-58.

19. Макаренко Е.Л. Лесные пожары и их последствия в Центральной экологической зоне Байкальской природной территории // Интерактивная наука. 2016. № 5. C. 9-12.

20. Матвеев П.М. Последствия пожаров в лиственничных биогеоценозах на многолетней мерзлоте. Красноярск: СибГТУ, 2006. 268 с.

21. Медведков A.A. Индикация состояния мерзлотнотаежных ландшафтов на южной периферии криолитозоны в условиях изменяющегося климата // Вестн. Моск. обл. ун-та. Сер. Естест. науки. 2018. № 1. C. $18-28$.

22. Медведков A.A. Картографирование криогенных ландшафтов на основе анализа тепловых снимков / ИнтерКарто/ИнтерГИС. 2016. Т. 22. № 1. С. 380-384.

23. Медведков A.A. Мерзлотные ландшафты - источники повышенной пожароопасности сибирской тайги в условиях потепления климата / Анализ, прогноз и управление природными рисками в современном мире (ГЕОРИСК-2015). М.: РУДН, 2015. Т. 2. С. 483-486.

24. Медведков A.A. Подходы к оценке противопожарной функции лесных ландшафтов в условиях бореальной криолитозоны / Анализ, прогноз и управление природными рисками с учетом глобального изменения климата (ГЕОРИСК-2018). М.: РУДН, 2018. Т. 2. С. 209-213.

25. Медведков A.A. Среднетаежные геосистемы Приенисейской Сибири в условиях меняющегося климата. М.: МАКС Пресс, 2016. 144 с.

26. Мягков М.С. Влияние мегаполиса Москва на величину испарения // Метеорология и гидрология. 2005. № 3. C. 78-84.
27. Павлов А.В., Ананьева Г.В. Оценка современных изменений температуры воздуха на территории криолитозоны России // Криосфера Земли. 2004. T. VIII. № 2. C. 3-9.

28. Позняков Л.К. Мерзлотное лесоведение. Новосибирск: Наука, 1986. 192 с.

29. Пономарев Е.И., Харук В.И., Якимов Н.Д. Результаты и перспективы спутникового мониторинга природных пожаров Сибири // Сиб. лес. журн. 2017. № 5. С. 25-36.

30. Потемкина Т.Г., Потемкин В.Л., Гусева Е.А. Озерно-речная система оз. Байкал-р. Селенга в условиях изменяющейся окружающей среды // Изв. СО РАЕН. Геология, поиски и разведка рудных месторождений. 2016. № 2 (55). С. 103-115.

31. Потемкина Т.Г., Потемкин В.Л., Федотов А.П. Климатические факторы как риски современных экологических изменений в береговой зоне озера Байкал // Геология и геофизика. 2018. Т. 59. № 5. C. 690-702.

32. Спурр С.Г., Барнес Б.В. Лесная экология: пер. с 3-го англ. изд. / Под ред. С.А. Дыренкова. М.: Лесная промышленность, 1984. 480 с.

33. Тепловодообмен в мерзлотных ландшафтах Восточной Сибири и его факторы / Отв. ред. А.Г. Георгиади, А.Н. Золотокрылин. М.-Тверь: Триада, 2007. $575 \mathrm{c}$.

34. Цветков П.А., Буряк Л.В. Исследование природы пожаров в лесах Сибири // Сиб. лес. журн. 2014. № 3. C. $25-42$.

35. Шимараев М.Н., Куимова Л.Н., Синюкович В.Н., Цехановский В.В. Климат и гидрологические процессы в бассейне оз. Байкал в XX столетии // Meтеорология и гидрология. 2002. № 3. С. 71-77.

36. Щербов Б.Л., Страховенко В.Д., Сухоруков Ф.В. Экогеохимическая роль лесных пожаров в Байкальском регионе // География и природные ресурсы. 2008. № 2. С. 60-66.

37. Arroyo L.A., Pasccual C., Manzanera J.A. Fire models and methods to map fuel types: The role of remote sensing // Forest Ecol. and Manag. 2008. V. 256. № 6. P. 1239-1252.

38. Desjardins R.L., MacPherson J.I., Schuepp P.H., Hayhoe $H$. Airborne flux measurements of $\mathrm{CO}_{2}$, sensible and latent heat over the Hudson Bay lowland // J. Geophys. Res. 1994. V. 99. № D1. P. 1551-1562.

39. Hansen M.C., DeFries R.S., Townshend J.R.G., Sohlberg R., Dimiceli $C$., Carroll $M$. Towards an operational MODIS continuous field of percent tree cover algorithm: examples using AVHRR and MODIS data // Remote Sensing of Env. 2002. V. 83. P. 303-319.

40. Peterson S.Y., Franlin J., Roberts D.A., Wagtendonk W. van. Mapping fuels in Yosemite National Park // Canad. J. of Forest Res. 2013. V. 43. № 1. P. 7-17.

41. Southworth J. An assessment of Landsat TM band 6 thermal data for analyzing land cover in tropical dry forest regions // Int. J. of Remote Sensing. 2004. V. 25. № 4. P. 689-706.

42. Ritter J.A., Barrick J.D., Watson C.E., Sachse G.W., Gregory G.L., Anderson B.E., Woerner M.A., Collins J.F. Airborne boundary layer flux measurements of trace species over Canadian boreal forest and Northern wetland region // J. Geophys. Res. V. 99. № D1. P. 1671-1685. 


\title{
Fire-Fighting Capability of Forests in Water Protection Zone of Lake Baikal (Case Study of Baikal-Lena Nature Reserve)
}

\author{
A. A. Medvedkovi, 2, * and M. V. Kotova ${ }^{1, * *}$ \\ ${ }^{1}$ Lomonosov Moscow State University, Moscow, Russia \\ ${ }^{2}$ Moscow Region State University, Moscow, Russia \\ *e-mail:a-medvedkov@bk.ru \\ **e-mail: mariakot121212@gmail.com
}

\begin{abstract}
The methodology of comparative assessment the fire-fighting capability of different forest types based on processing of thermal infrared imaging Landsat TM data and surface temperatures of forest landscapes with different bioproduction characteristics received on that basis is reviewed. This methodology has been applied to modal geosystems of Baikal-Lena Nature Reserve located in water protection zone of Lake Baikal. The opportunity to use surface temperatures for the assessment of fire-fighting role of different forest types is based on the equation of heat balance (R) of the Earth surface as the sum of heat of evaporation (i.e. a stream of latent heat) and turbulent flow from underlying surface. Thermal values were received by interpretation thermal infrared images and reflect the degree of the emission of obvious heat by a landscape. The more obvious heat flow emissions, the less latent heat flow in form of transpiration and physical evaporation from vegetation canopy and more near surface temperatures values. The values of surface temperatures and NDVI and NDMI indexes were analyzed and information about registered hot spots due to extremely hot summer periods from years 2011 till 2017 was applied to identify more vulnerable forest types between modal geosystems of Baikal-Lena Nature Reserve. Most fire vulnerable forest landscapes coincide with intermountain depressions valleys, lowlands, bottom of intermountain basins, submontane uplands and smooth hillsides. Those have different degree of waterlogged areas with islands of frozen rocks and low values of phytomass. These nature complexes are more fire-dangerous in periods of long droughts due to lower transpiration potential and less influence on micro- and mesoclimat as compared with forest on unfrozen rocks.
\end{abstract}

Keywords: natural fire hazard factors, forest burning, Siberian taiga, transpiration potential, thermal infrared range, permafrost forest, Baikal natural territory

\section{REFERENCES}

1. Baikal. Atlas [Baikal. Atlas]. Galazii G.I., Ed. Moscow: Roskartographiya Publ., 1993. 160 p.

2. Baldina E.A., Grishchenko M.Yu. Methodics for deciphering multi-temporal satellite images in the thermal infrared range. Vestn. Mosk. Univ., Ser. 5: Geogr., 2014, no. 3, pp. 35-41 (In Russ.).

3. Bobylev S.N., Minaev V.S., Solov'ev S.V., Tret'yakov V.V. Ekologo-ekonomicheskii indeks regionov $R F$ [Ecological and Economic Index of the Regions of the Russian Federation.] Moscow: WWF, 2012. $150 \mathrm{p}$.

4. Bobylev S.N., Stetsenko A.V. Forest projects: climate change and ecosystem services. Tr. S.-Peterb. Nauchn.Issled. Inst. Lesnogo Khozyaistva, 2016, no. 3, pp. 77-89 (In Russ.).

5. Borisov B.Z., Fedorov P.P., Chikidov I.I., Desyatkin A.R. Identifying of permafrost in the zone of their island distribution through the thermal channels of satellite images Landsat-7 ETM+. Usp. Sovrem. Estestvoznaniya, 2017, no. 5, pp. 78-82. (In Russ.).

6. Budyko M.I. Global'naya ekologiya [Global Geoecology]. Moscow: Mysl' Publ. 1977. 328 p.

7. Volokitina A.V. Improving the assessment of the natural fire hazard in nature reserves. Geogr. Nat. Resour., 2017, no. 1, pp. $46-51$.

8. Volokitina A.V., Sofronov A.M. Klassifikatsiya i kartografirovanie rastitel'nykh goryuchikh materialov [Classification and Mapping of Vegetable Combustible Materials]. Novosibirsk: Sibir. Otd-e RAN, 2002. 306 p.
9. Vykhristyuk M.M. Fitoklimat pribrezhnykh lesov severnogo Baikala [Phytoclimate of the Coastal Forests of Northern Baikal]. Novosibirsk: Nauka Publ. 1980. $216 \mathrm{p}$.

10. Galenko E.P. Temperature regime of air of an oldgrowth spruce tree of the middle taiga. Izv. Vyssh. Ucheb. Zaved. Lesnoi Zh., 2013, no. 3, pp. 45-56 (In Russ.).

11. Galenko E.P. Energy factors of productivity of coniferous forests of the northern taiga. Izv. Akad. Nauk, Ser. Geogr., 1976, no. 4, pp. 84-89 (In Russ.).

12. Gorshkov S.P. Integrated environmental and economic indices and the Kyoto protocol problem. Probl. Reg. Ekol., 2013, no. 4, pp. 256-261 (In Russ.).

13. Gorshkov S.P. Organization of the biosphere and sustainable development. Zhizn' Zemli, 2015, vol. 37, pp. 62-84 (In Russ.).

14. Gusev V.G., Lopukhova E.L., Dubovyi V.K. Classification and general properties of forest combustible materials. Izv. Vyssh. Ucheb. Zaved. Lesnoi Zh., 2012, no. 1(325), pp. 134-145 (In Russ.).

15. Evdokimenko M.D. Factors of fires in the Baikal forests. Geogr. Prir. Resur., 2011, no. 3, pp. 51-57 (In Russ.).

16. Zolotokrylin A.N. Klimaticheskoe opustynivanie [Climate Desertification]. Moscow: Nauka Publ., 2003. $246 \mathrm{p}$.

17. Karpechko Yu.V., Bondarik N.L. Gidrologicheskaya rol' lesokhozyaistvennykh i lesopromyshlennykh rabot $v$ taezhnoi zone Evropeiskogo Severa Rossii [The Hydrologi- 
cal Role of Forestry and Forestry Operations in the Taiga Zone of the European North of Russia]. Petrozavodsk: KarNTs RAN, 2010. 225 p.

18. Kurbatskii N.P. Study of the quantity and properties of forest combustible materials. In Vopr. lesnoi pirologii [Questions of Forest Pyrology]. Krasnoyarsk: Inst. Lesa i Drevesiny Sibir. Otd. AN SSSR, 1970, pp. 5-58 (In Russ.).

19. Makarenko E.L. Forest fires and their consequences in the Central Ecological Zone of the Baikal Natural Territory. Interaktivnaya Nauka, 2016, no. 5, pp. 9-12 (In Russ.).

20. Matveev P.M. Posledstviya pozharov v listvennichnykh biogeotsenozakh na mnogoletnei merzlote [The Consequences of Fires in Larch Biogeocenoses in Permafrost]. Krasnoyarsk: Sibir. Gos. Tekhn. Univ., 2006. 268 p.

21. Medvedkov A.A. Indication of the state of permafrosttaiga landscapes on the southern periphery of the permafrost zone in a changing climate. Vestn. Mosk. Gos. Obl. Univ., Ser.: Estestvennye Nauki, 2018, no. 1, pp. 18-28 (In Russ.).

22. Medvedkov A.A. Mapping of cryogenic landscapes based on the analysis of thermal images. InterKarto/InterGIS, 2016, vol. 22, no. 1, pp. 380-384 (In Russ.).

23. Medvedkov A.A. Permafrost landscapes - sources of increased fire hazard of the Siberian taiga in conditions of climate warming. In Analiz, prognoz $i$ upravlenie prirodnymi riskami v sovremennom mire (GEORISK-2015) [Analysis, Prediction and Management of Natural Risks in Modern World (GEORISK-2015)]. Moscow: RUDN, 2015, vol. 2, pp. 483-486 (In Russ.).

24. Medvedkov A.A. Approaches to the assessment of the fire function of forest landscapes in the conditions of the boreal permafrost zone. In Analiz, prognoz i upravlenie prirodnymi riskami $v$ sovremennom mire (GEORISK 2015) [Analysis, Prediction and Management of Natural Risks in Modern World (GEORISK-2015)]. Moscow: RUDN, 2018, vol. 2, pp. 209-213 (In Russ.).

25. Medvedkov A.A. Srednetaezhnye geosistemy Prieniseiskoi Sibiri v usloviyah menyayushchegosya klimata [Midtaiga Geosystems of the Yenisei Siberia in a Changing Climate]. Moscow: MAKS Press, 2016. 144 p.

26. Myagkov M.S. The influence of the Moscow metropolis on the amount of evaporation. Meteorol. Gidrol., 2005, no. 3, pp. 78-84 (In Russ.).

27. Pavlov A.V., Anan'eva G.V. Assessment of current changes in air temperature in the cryolithozone of Russia. Kriosfera Zemli, 2004, vol. 8, no. 2, pp. 3-9 (In Russ.).

28. Poznyakov L.K. Merzlotnoe lesovedenie [Permafrost Forestry]. Novosibirsk: Nauka Publ. 1986. 192 p.

29. Ponomarev E.I., Kharuk V.I., Yakimov N.D. Results and prospects of satellite monitoring of natural fires in Siberia. Sibir. Lesn. Zh., 2017, no. 5, pp. 25-36 (In Russ.).
30. Potemkina T.G., Potemkin V.L., Guseva E.A. The lake-river system Lake Baikal - the Selenga River in a changing environment conditions. Izv. SO RAEN. Geol., Poiski i Razvedka Rudnykh Mestorozhdenii, 2016, no. 2 (55), pp. 103-115 (In Russ.).

31. Potemkina T.G., Potemkin V.L., Fedotov A.P. Climatic factors as risks of recent ecological changes in the shallow zone of Lake Baikal. Russ. Geol. i Geophys., 2018, vol. 59, no. 5, pp. 690-702 (In Russ.).

32. Spurr S.G., Barnes B.V. Forest Ecology. New York: Ronald Press, 1973. 575 p.

33. Teplovodoobmen $v$ merzlotnykh landshaftakh Vostochnoi Sibiri i ego faktory [Heat and Moisture Exchange in Permafrost Landscapes of Eastern Siberia and its Factors]. Georgiadi A.G., Zolotokrylin A.N., Eds. M., Tver: Triada Publ., 2007. 575 p.

34. Tsvetkov P.A., Buryak L.V. Studies of fire nature in the forests of Siberia. Sib. Lesnoi Zh., 2014, no. 3, pp. 2542 (In Russ.).

35. Shimaraev M.N., Kuimova L.N., Sinyukovich V.N., Tsekhanovskii V.V. Climate and hydrological processes in Lake Baikal in the 20th century. Russ. Meteorol. Hydrol., 2002, no. 3, pp. 71-77.

36. Shcherbov B.L., Strakhovenko V.D., Sukhorukov F.V. The ecogeochemical role of forest fires in the Baikal region. Geogr. Nat. Resour., 2008, no. 2, pp. 60-66 (In Russ.).

37. Arroyo L.A., Pasccual C., Manzanera J.A. Fire models and methods to map fuel types: The role of remote sensing. Forest Ecol. Manag., 2008, vol. 256, no. 6, pp. 1239-1252.

38. Desjardins R.L., MacPherson J.I., Schuepp P.H., Hayhoe H. Airborne flux measurements of CO2, sensible and latent heat over the Hudson Bay lowland. J. Geophys. Res., 1994, vol. 99, no. D1, pp. 1551-1562.

39. Hansen M.C., DeFries R.S., Townshend J.R.G., Sohlberg R., Dimiceli C., Carroll M. Towards an operational MODIS continuous field of percent tree cover algorithm: examples using AVHRR and MODIS data. Remote Sens. Environ., 2002, vol. 83, pp. 303-319.

40. Peterson S.Y., Franlin J., Roberts D.A., van Wagtendonk J.W. Mapping fuels in Yosemite National Park. Can. J. For. Res., 2013, vol. 43, no. 1, pp. 7-17.

41. Southworth J. An assessment of Landsat TM band 6 thermal data for analyzing land cover in tropical dry forest regions. Int. J. Remote Sens., 2004, vol. 25, no. 4, pp. 689-706.

42. Ritter J.A., Barrick J.D., Watson C.E., Sachse G.W., Gregory G.L., Anderson B.E., Woerner M.A., Collins J.F. Airborne boundary layer flux measurements of trace species over Canadian boreal forest and Northern wetland region. J. Geophys. Res., vol. 99, no D1, pp. 1671-1685. 